\title{
OSTEOCHONDRAL AUTOLOGOUS TRANSPLANTATION FOR TREATING CHONDRAL LESIONS IN THE PATELLA
}

\begin{abstract}
Moises Cohen', Joicemar Tarouco Amaro², Ricardo de Souza Campos Fernandes ${ }^{3}$, Gustavo Gonçalves Arliani ${ }^{4}$,
\end{abstract} Diego da Costa Astur ${ }^{4}$, Camila Cohen Kaleka ${ }^{5}$, Abdalla Skaf $^{6}$

\section{ABSTRACT}

Objective: The primary aim of this study was to assess the clinical and functional evolution of patients with total-thickness symptomatic cartilaginous injury of the patellar joint surface, treated by means of osteochondral autologous transplantation. Methods: This prospective study was conducted from June 2008 to March 2011 and involved 17 patients. The specific questionnaires of Lysholm, Kujala and Fulkerson were completed preoperatively and one year postoperatively in order to assess the affected knee, and SF-36 was used to assess these patients' general quality of life. The nonparametric paired
Wilcoxon test was used for statistical analysis on the pre and postoperative questionnaires. The data were analyzed using the SPSS for Windows software, version 16.0, and a significance level of 5\% was used. Results: The Lysholm preoperative and postoperative average scores were 54.59 and 75.76 points $(p<0.05)$. The Fulkerson pre and postoperative average scores were 52.53 and 78.41 points $(p<0.05)$. Conclusions: We believe that autologous osteochondral transplantation is a good treatment method for total-thickness symptomatic chondral lesions of the joint surface of the patella.

Keywords - Cartilage Articular; Patella; Orthopedics

\section{INTRODUCTION}

Treatment of joint cartilage lesions remains a major challenge today. This is because of the inherent characteristic of low regenerative capacity shown by this tissue ${ }^{(1)}$. These lesions are relatively common and, in a retrospective study on 31,516 arthroscopic procedures carried out, they occurred in 19,827 of the procedures $(63 \%)$. More than $60 \%$ of the chondral lesions encountered were classified as grades III or $\mathrm{IV}^{(2)}$. They may cause discomfort and effusion in the knee and, occasionally, may contribute towards early development of osteoarthrosis ${ }^{(3)}$.

The patella is a sesamoid bone with the greatest joint cartilage thickness in the human body. This great thickness increases the area over which the femoropatellar joint contact forces are distributed ${ }^{(4-6)}$.
The forces generated in this joint through normal day-to-day activities are extremely high and may reach 6.5 times the body weight ${ }^{(7)}$. Any cartilage lesion affecting the total thickness present in the patella impedes the normal propagation of these forces and may cause increased injury, pain and functional debilitation $^{(5)}$. Consequently, osteochondral defects in the patella present particularly difficult and challenging treatment ${ }^{(8)}$.

Over the last few decades, a variety of techniques have been developed in attempting to solve these difficulties, with varying success rates $^{(1,8-17)}$. These include an enormous range of treatment options such as microfractures, autologous chondrocyte implantation, use of allografts and autologous osteochondral transplantation (AOT). However, this last technique

1 - Adjunct Professor and Head of the Department of Orthopedics and Traumatology, Federal University of São Paulo, São Paulo, SP, Brazil.

2 - Attending Physician in the Cohen Institute of Orthopedics, Rehabilitation and Sports Medicine, São Paulo, SP, Brazil.

3 - Trainee at the Cohen Institute of Orthopedics, Rehabilitation and Sports Medicine, São Paulo, SP, Brazil.

4 - Member of the Sports Traumatology Center (CETE), Department of Orthopedics and Traumatology, Federal University of São Paulo, São Paulo, SP, Brazil.

5 - Physician in the Knee Group, School of Medical Sciences, Santa Casa de São Paulo, São Paulo, SP, Brazil.

6 - Radiologist in the Imaging Diagnostics Clinic, Hospital do Coração, São Paulo, SP, Brazil.

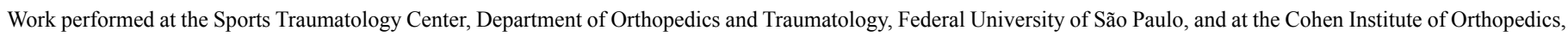
Rehabilitation and Sports Medicine, São Paulo.

Correspondence: Rua Borges Lagoa 783, 5ªndar, Vila Clementino, 04038-032 São Paulo, SP. E-mail: m.cohen@uol.com.br

Work received for publication: May 8, 2011; accepted for publication: August 31, 2011.

The authors declare that there was no conflict of interest in conducting this work 
using autologous material is the only one that provides immediate stable restoration of the height and shape of the joint surface, thereby reducing the filling of the defect with fibrocartilage ${ }^{(14)}$.

AOT involves removal of small cylindrical blocks of healthy cartilage with subchondral bone from areas that are less subjected to body weight and their transportation to the defect site. Because of these characteristics, AOT is an attractive option for treating cartilaginous defects ${ }^{(8)}$.

Although many studies have already been published describing successful use of AOT in treating cartilaginous defects in the femoral condyles and trochlea, studies evaluating this procedure performed in the patella are rare ${ }^{(8,11,12,17,18)}$.

The primary objective of this study was to evaluate the clinical and functional evolution of patients with symptomatic full-thickness cartilaginous lesions of the joint surface, treated with AOT.

\section{MATERIALS AND METHODS}

This prospective study on a consecutive case series involved 17 patients who underwent AOT to treat full-thickness cartilaginous lesions of the patella. The study was conducted between June 2008 and March 2011.

The inclusion criteria of the study were: age less than 60 years; presence of symptoms (anterior knee pain); physical examination for chondral lesions of the patella; grade III or IV chondral lesions according to the classification of the International Cartilage Repair Society (ICRS); and cartilaginous lesions of size 1 to $4 \mathrm{~cm}^{2(19)}$.

The exclusion criteria were: lesions smaller than $1 \mathrm{~cm}^{2}$ or greater than $4 \mathrm{~cm}^{2}$; need for concomitant reconstruction of the anterior cruciate ligament (ACL); infection; rheumatoid arthritis; and meniscal deficiency.

Before the operation and one year after the operation, the specific Lysholm, Kujala and Fulkerson questionnaires were answered in order to assess the affected knee, and the SF-36 to assess the patients' general quality of life. The mean length of clinical follow-up was 19.8 months (minimum of 12 months and maximum of 33 months).

A careful physical examination was conducted in order to assess femoropatellar instability, patellar tilt, crepitation and patellar alignment. In addition, radiographs were produced on all the patients, in anteroposterior view, lateral view at $30^{\circ}$ of flexion and Merchant position, in order to evaluate the patellar tilt and height, using the Caton-Deschamps method. Computed tomography and magnetic resonance imaging (MRI) were performed to assess the trochlear and patellar morphology, measure TA-GT and characterize any chondral lesions present. These physical and supplementary examinations had the aims of making an overall assessment on the femoropatellar joint and defining the surgical procedures that would be carried out.

After the surgical procedure, MRI was performed on the operated knee in all cases, 12 months after the operation, in order to assess the following: repair tissue in the cartilage; degree of filling; incorporation of the grafted osteochondral cylinder; congruence of the graft with the adjacent cartilage; and donor site.

The patients' ages ranges from 16 to 59 years (mean: $38.06 \pm 13.38$ years). Regarding sex, eight were female and nine $(52.9 \%)$ were male. In relation to side affected, there were eight right knees and nine left knees (52.9\%).

\section{Description of the surgical procedure}

All the surgical procedures were performed by the same senior surgeon (M.C.). Initially, arthroscopy was performed to make an overall assessment of the joint and confirm the clinical-radiological diagnosis of a cartilaginous lesion of the joint face of the patella.

Once the diagnosis had been confirmed, the arthroscopy was halted and a longitudinal parapatellar access route was created, from the apex of the patella to its lower limit, which was medial or lateral depending on the patellar facet affected (Figure 1A). After dissection in layers and identification of the joint capsule, arthrotomy was performed and the patella was everted to achieve perfect viewing of its joint surface, using a Kirschner wire as a lever to facilitate presentation of the lesion (Figure 1B).

At this moment, using a diameter guide marked out in millimeters, the size of the lesion was measured for subsequent determination of the size of the donor osteochondral cylinder (Figure 1C).

The instrument used for harvesting the graft from the donor area was a few millimeters bigger than the one that would serve to drill out the receptor area. Then, using an appropriate instrument, the previously measured base of the cartilaginous lesion was drilled out using a bit with the previously measured diameter (Figures 1D and 1E). On average, the length of the osteochondral cylinder was 10 millimeters. Following 
this, the receptor tunnel was dilated using a specific tool, and the osteochondral graft was harvested with the knee extended, at a peripheral location without exposure to load, above the femoropatellar joint area (Figures 1F and 1G). All the drill holes were made perpendicularly to the joint surface. Next, the osteochondral cylinder was inserted, with the remainder of the patellar joint cartilage (Figures 1I and 1J).

\section{Postoperative rehabilitation}

During the immediate postoperative period, the rehabilitation protocol of Bobic ${ }^{(20)}$ and Hangody et $\mathrm{al}^{(21)}$ was followed for all the patients. This involved early release for range-of-motion exercises, both in water and out of it. Gait training in a deep pool was started immediately, and exercises on an ergometric bicycle were started after three to four weeks, according to how these were tolerated, along with progressive muscle strengthening, sensory-motor training and stretching. Partial loading on the operated limb was maintained for two to three weeks. Patients were only released to go running after four to six months, and to do contact sports after six months.

\section{STATISTICAL ANALYSIS}

The nonparametric paired Wilcoxon test was used to statistically analyze the pre and postoperative scores from the Lysholm, Fulkerson, Kujala and SF-36 questionnaires.

For correlation assessments on the specific knee questionnaires (Lysholm, Fulkerson and Kujala) and the subscales of the SF-36, the Spearman correlation test was used.

The data were analyzed using the SPSS for Windows software, version 16.0, and a significance level of $5 \%$ was used.

\section{RESULTS}

A single osteochondral graft unit of $10 \times 15 \mathrm{~mm}$ was used in all cases except one, which presented a larger lesion for which two osteochondral lesions were used.

In total, seven procedures associated with treatment for cartilaginous lesions, involving autologous osteochondral transplantation, were performed on different patients. In one case, concomitant reconstruction of the medial patellofemoral ligament was

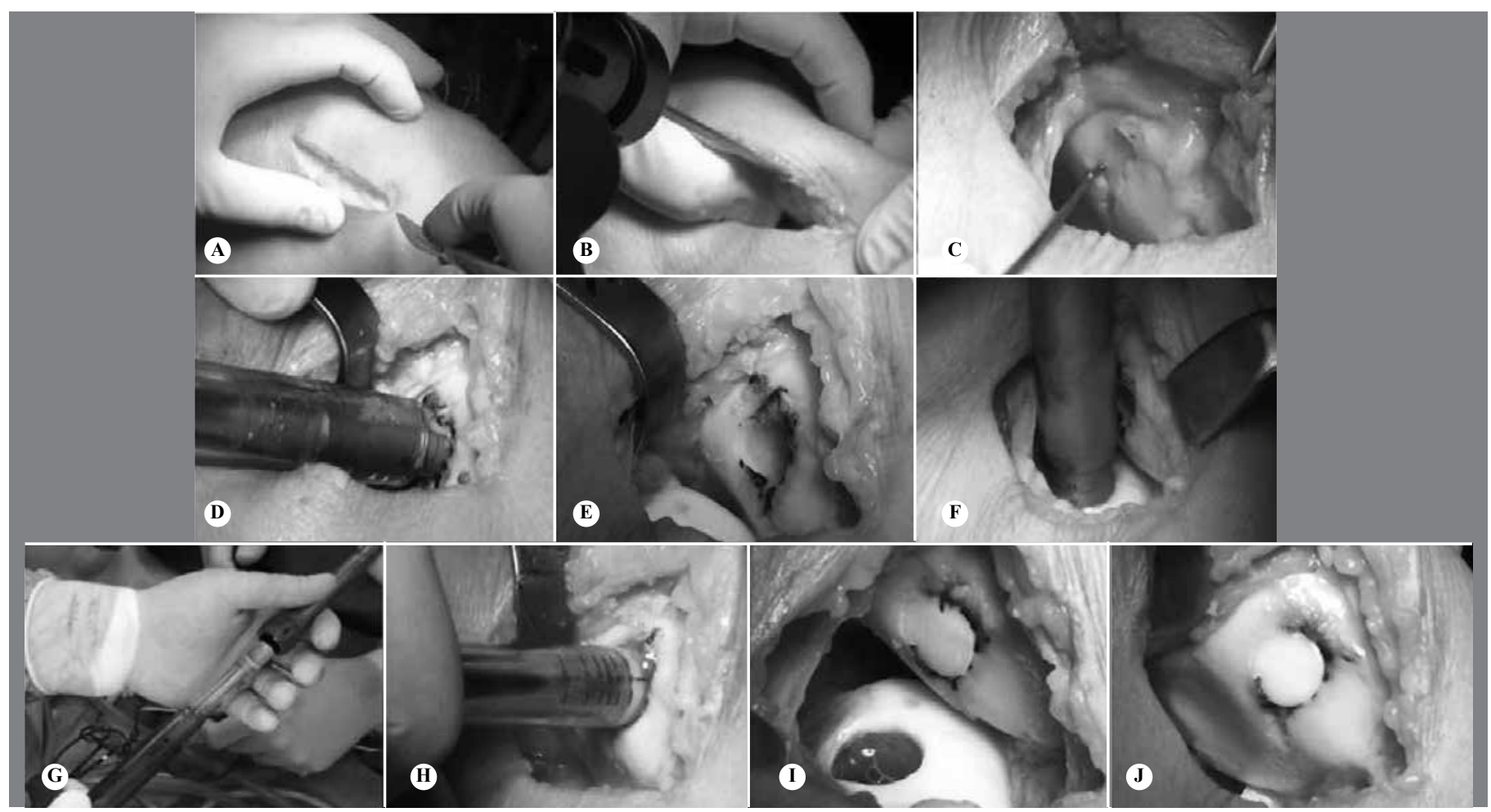

Figure 1 - Surgical technique for autologous osteochondral transplantation in cases of patellar chondral lesion. (A) Incision and medial parapatellar arthrotomy. (B) Implantation of Kirschner wire for better manipulation patella. (C) Identification of osteochondral lesion on the medial patella facet. (D) Removal of damaged area using instruments. (E) Appearance of the receptor site. (F) Removal of donor osteochondral graft from the upper region of the medial femoral condyle, outside of the loaded area. (G) Appearance of the donor osteochondral plug before implantation. $(\mathrm{H})$ Implantation of the osteochondral graft in the receptor site. (I) Final appearance of the donor and receptor sites. (J) Final appearance of the procedure, showing good alignment with adjacent cartilage and filling of the injured area. 
performed because of a traumatic injury. In another six cases, we decided to perform lateral release, given that these patients presented excessive lateral patellar tilt, in association with a chondral lesion and consequent overload on the lateral facet.

Regarding the anatomical location of the lesion, the lateral facet was affected in nine cases $(53 \%)$; the medial facet was affected in seven cases; and the location was central on the patella in one case.

The functional results are described in Table 1. The mean preoperative Lysholm score was $54.59 \pm 25.99$ points (range: 9-98), and the mean postoperative score was $75.76 \pm 18.89$ points (range: $36-100)(p<0.05)$. The mean preoperative Fulkerson score was $52.53 \pm 25.80$ points (range: 2-93) and the mean postoperative score was $78.41 \pm 18.76$ points (range: $21-100)(\mathrm{p}<0.05)$. The mean preoperative Kujala score was $49.82 \pm 22.04$ points (range: $12-81$ ) and the mean postoperative score was $73.47 \pm 17.66$ points (range: $43-100)(p<0.05)$. The pre and postoperative evaluations on the subscales of the SF-36 are shown in Table 2.

Comparison between the specific knee assessments and the subscales of the SF-36 showed that there was a correlation between the best Kujala score results obtained and changes to patients' pain and general state of health $(\mathrm{p}<0.05)$ (Table 3$)$.

There were no complications among the 17 cases operated during the study period.

\section{DISCUSSION}

Treating osteochondral defects in the patella is generally a great challenge for orthopedists. This is due both to the intrinsic characteristics of the femoropatellar joint, such as its orientation, morphology, mobility and mechanical demand, and to the low potential for cartilage regeneration ${ }^{(22)}$.

Many techniques have been developed for treating these lesions. Microfracturing is used to stimulate lesion healing, but this technique gives rise, at the lesion site, to fibrocartilaginous tissue of quality inferior

Table 1 - Functional results before and after the operation.

\begin{tabular}{c|c|c|c|c|c|c|c}
\hline Variable & Mean & SD & Median & Minimum & Maximum & $\mathbf{N}$ & $\boldsymbol{p}$ \\
\hline $\begin{array}{c}\text { Lysholm } \\
\text { (before) }\end{array}$ & 54.59 & 25.99 & 46 & 9 & 98 & 17 & 0.019 \\
\hline Lysholm (after) & 75.76 & 18.89 & 80 & 36 & 100 & 17 & \\
\hline $\begin{array}{c}\text { Fulkerson } \\
\text { (before) }\end{array}$ & 52.53 & 25.80 & 53 & 2 & 93 & 17 & 0.001 \\
\hline Fulkerson (after) & 78.41 & 18.76 & 82 & 21 & 100 & 17 & \\
\hline Kujala (before) & 49.82 & 22.04 & 57 & 12 & 81 & 17 & 0.002 \\
\hline Kujala (after) & 73.47 & 17.66 & 74 & 43 & 100 & 17 & \\
\hline
\end{tabular}

Table 2 - SF-36 results before and after the operation.

\begin{tabular}{|c|c|c|c|c|c|c|c|}
\hline Variable & Mean & SD & Median & Minimum & Maximum & $\mathbf{N}$ & $p$ \\
\hline $\begin{array}{l}\text { Functional } \\
\text { capacity } \\
\text { (before) }\end{array}$ & 45.88 & 15.02 & 50 & 25 & 75 & 17 & \multirow[t]{2}{*}{0.128} \\
\hline $\begin{array}{l}\text { Functional } \\
\text { capacity (after) }\end{array}$ & 63.53 & 30.09 & 70 & 10 & 95 & 17 & \\
\hline $\begin{array}{l}\text { Limitation due } \\
\text { to physical } \\
\text { factors (before) }\end{array}$ & 30.88 & 35.94 & 25 & 0 & 100 & 17 & \multirow{2}{*}{0.013} \\
\hline $\begin{array}{l}\text { Limitation due } \\
\text { to physical } \\
\text { factors (after) }\end{array}$ & 72.06 & 38.41 & 100 & 0 & 100 & 17 & \\
\hline Pain (before) & 47.82 & 21.19 & 41 & 21 & 100 & 17 & \multirow{2}{*}{0.026} \\
\hline Pain (after) & 72.35 & 26.36 & 74 & 20 & 100 & 17 & \\
\hline $\begin{array}{l}\begin{array}{l}\text { General state } \\
\text { of health } \\
\text { (before) }\end{array} \\
\end{array}$ & 73.59 & 19.75 & 72 & 47 & 100 & 17 & \multirow[t]{2}{*}{0.139} \\
\hline $\begin{array}{l}\text { General state } \\
\text { of health (after) }\end{array}$ & 78.65 & 17.76 & 82 & 47 & 100 & 17 & \\
\hline Vitality (before) & 61.47 & 21.20 & 60 & 20 & 95 & 17 & \multirow{2}{*}{0.013} \\
\hline Vitality (after) & 74.41 & 18.53 & 80 & 25 & 95 & 17 & \\
\hline $\begin{array}{l}\text { Social factors } \\
\text { (before) }\end{array}$ & 59.50 & 17.96 & 50 & 38 & 100 & 17 & \multirow{2}{*}{0.021} \\
\hline $\begin{array}{l}\text { Social factors } \\
\text { (after) }\end{array}$ & 74.27 & 22.30 & 75 & 25 & 100 & 17 & \\
\hline $\begin{array}{l}\text { Limitation due } \\
\text { to emotional } \\
\text { factors (before) }\end{array}$ & 39.94 & 35.72 & 33.3 & 0 & 100 & 17 & \multirow{2}{*}{0.034} \\
\hline $\begin{array}{l}\text { Limitation due } \\
\text { to emotional } \\
\text { factors (after) }\end{array}$ & 74.75 & 41.47 & 100 & 0 & 100 & 17 & \\
\hline $\begin{array}{l}\text { Mental health } \\
\text { (before) }\end{array}$ & 69.65 & 19.39 & 64 & 40 & 100 & 17 & \multirow{2}{*}{0.234} \\
\hline $\begin{array}{l}\text { Mental health } \\
\text { (after) }\end{array}$ & 75.76 & 21.19 & 84 & 20 & 100 & 17 & \\
\hline
\end{tabular}

Results from paired Wilcoxon test.

Table 3 - Correlation between the specific knee scales and the subscales of the SF-36.

\begin{tabular}{|c|c|c|c|c|}
\hline \multicolumn{2}{|l|}{ Correlação } & \begin{tabular}{|c|} 
Lysholm \\
(alteration)
\end{tabular} & \begin{tabular}{|c|}
$\begin{array}{c}\text { Fulkerson } \\
\text { (alteration) }\end{array}$ \\
\end{tabular} & $\begin{array}{c}\text { Kujala } \\
\text { (alteration) }\end{array}$ \\
\hline \multirow{3}{*}{$\begin{array}{l}\text { Functional capacity } \\
\text { (alteration) }\end{array}$} & $r$ & 0.293 & 0.389 & 0.305 \\
\hline & $p$ & 0.253 & 0.123 & 0.233 \\
\hline & $\mathrm{N}$ & 17 & 17 & 17 \\
\hline \multirow{3}{*}{$\begin{array}{l}\text { Limitation due to physical } \\
\text { factors (alteration) }\end{array}$} & $r$ & -0.079 & -0.177 & 0.35 \\
\hline & $p$ & 0.764 & 0.497 & 0.168 \\
\hline & $\mathrm{N}$ & 17 & 17 & 17 \\
\hline \multirow{3}{*}{ Pain (alteration) } & $r$ & 0.412 & 0.461 & 0.540 \\
\hline & $p$ & 0.101 & 0.063 & 0.025 \\
\hline & $\mathrm{N}$ & 17 & 17 & 17 \\
\hline \multirow{3}{*}{$\begin{array}{l}\text { General state of health } \\
\text { (alteration) }\end{array}$} & $r$ & 0.337 & 0.427 & 0.645 \\
\hline & $p$ & 0.186 & 0.087 & 0.005 \\
\hline & $\mathrm{N}$ & 17 & 17 & 17 \\
\hline \multirow{3}{*}{ Vitality (alteration) } & $r$ & 0.224 & 0.307 & 0.311 \\
\hline & $p$ & 0.387 & 0.23 & 0.225 \\
\hline & $\mathrm{N}$ & 17 & 17 & 17 \\
\hline \multirow{3}{*}{$\begin{array}{l}\text { Social factors } \\
\text { (alteration) }\end{array}$} & $r$ & 0.09 & 0.081 & 0.342 \\
\hline & $p$ & 0.731 & 0.758 & 0.179 \\
\hline & $\mathrm{N}$ & 17 & 17 & 17 \\
\hline \multirow{3}{*}{$\begin{array}{l}\text { Limitation due to } \\
\text { emotional factors } \\
\text { (alteration) }\end{array}$} & $r$ & 0.279 & 0.141 & 0.379 \\
\hline & $p$ & 0.278 & 0.589 & 0.133 \\
\hline & $\mathrm{N}$ & 17 & 17 & 17 \\
\hline \multirow{3}{*}{$\begin{array}{l}\text { Mental health } \\
\text { (alteration) }\end{array}$} & $r$ & 0.316 & 0.226 & 0.436 \\
\hline & $p$ & 0.216 & 0.383 & 0.080 \\
\hline & $\mathrm{N}$ & 17 & 17 & 17 \\
\hline
\end{tabular}


to that of hyaline cartilage, and it deteriorates with time $^{(23)}$. On the other hand, treatment using autologous chondrocyte transplantation produces cartilage similar to hyaline. However, this technique is financially costly and requires a specialized center for in vitro cell culturing, an extensive period without any mechanical loading, extensive rehabilitation and two surgical procedures ${ }^{(24,25)}$.

Autologous osteochondral transplantation was introduced by Wagner in $1964^{(26)}$ and is capable of producing immediate congruence of the joint cartilage in a single procedure, by means of a grafted osteochondral plug. This enables early transmission of mechanical load at the site.

Nho et $\mathrm{al}^{(8)}$ demonstrated 22 cases in which AOT was used to treat lesions of the patellar cartilage. This produced a change in the International Knee Documentation Committee (IKDC) score from 47.2 before the operation to 74.4 during the postoperative follow-up. On the Activities of Daily Living (ADL) scale of the Knee Outcome Survey, the change was from 60.1 before to 84.7 after the operation, while the Short Form-36 (SF-36) score went from 64.0 before to 79.4 after the operation. In the same study, magnetic resonance imaging was used in 14 cases, four months after the surgery, and this demonstrated good filling with cartilage (67-100\%) and good incorporation of the osteochondral cylinder (71\%). That study concluded that patellar AOT was an effective form of treatment for focal chondral lesions of the patella and suggested that patients with patellar misalignment presented worse prognoses than did those with normal alignment. Our study presented very similar results from the assessments using the SF-36 and the specific knee scales, and we also observed good incorporation of the osteochondral cylinder on MRI, in all cases (Figures $2 \mathrm{~A}$ and $\mathrm{B}$, Figures $3 \mathrm{~A}$ and $\mathrm{B}$ and Figures $4 \mathrm{~A}$ and $\mathrm{B})$.

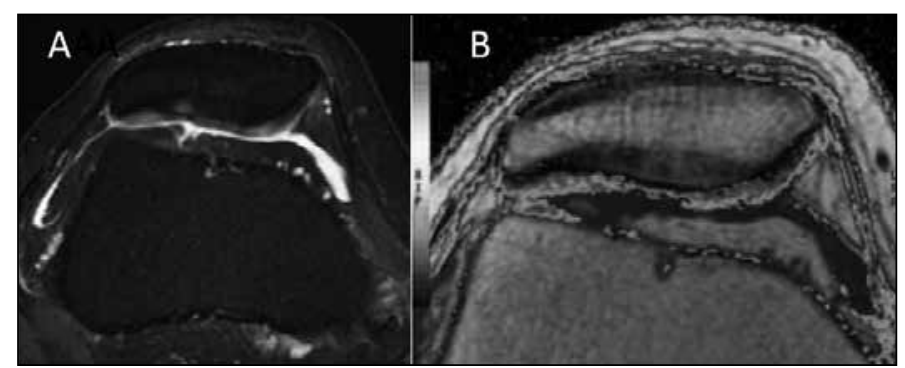

Figure 2 - (A) Magnetic resonance images in the axial plane; (B) Showing chondral lesion in the right knee.

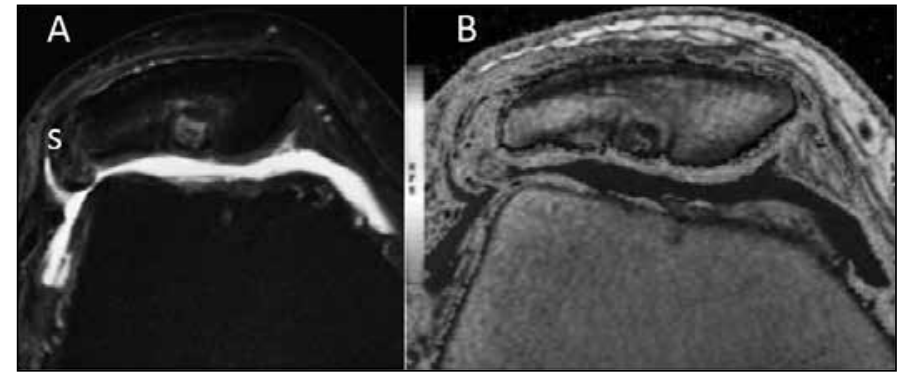

Figure 3 - (A) Magnetic resonance images in the axial plane; (B) Six months after patellar mosaicplasty on the right knee.

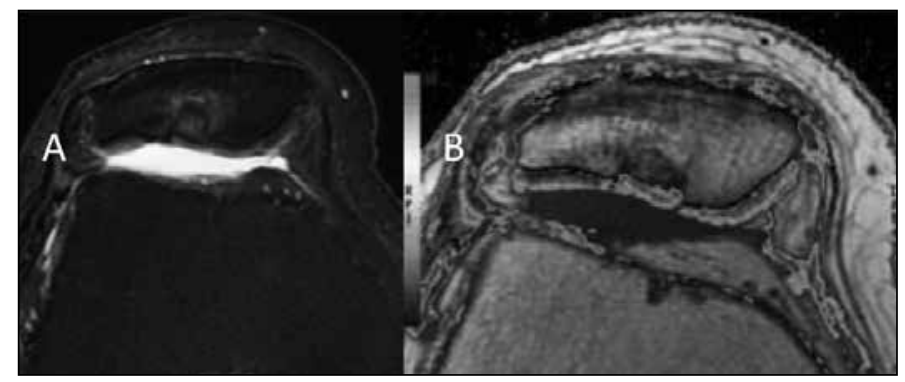

Figure 4 - (A) Magnetic resonance images in the axial plane; (B) One year after patellar mosaicplasty on the right knee.

Atik et al ${ }^{(12)}$ reported success in $85 \%$ of their cases of patellar cartilage lesion treated with mosaicplasty, and achieved a change in Lysholm score from 56 points before the operation to 86 after the operation.

In a retrospective study on 52 patients with full-thickness cartilage lesions who were treated using AOT (minimum follow-up of two years), Jakob et al $^{(27)}$ found that $86 \%$ of their cases showed significant improvement in knee function, according to the assessment criteria of the International Cartilage Repair Society (ICRS), and that at the final follow-up assessment, the proportion with good results went up to $92 \%$.

In our study, we obtained a mean change in Lysholm score from 55 points before the operation to 76 points after the operation. We believe that the higher scores obtained by Atik et $\mathrm{al}^{(12)}$ and Jakob et $\mathrm{al}^{(27)}$ related to the longer duration of postoperative follow-up and the younger age of the patients treated with patellar AOT, given that in our study, some of the patients were older, with degenerative lesions.

Hangody and Fules ${ }^{(11)}$ presented their 10 years of clinical experience with mosaicplasty, and demonstrated that $79 \%$ of their results were good and excellent, from 118 procedures on the patellofemoral joint. These results were inferior to those obtained from procedures on the femoral condyles $(92 \%$ with good results). 
In a randomized prospective study conducted in 2003 , Bentley et $\mathrm{al}^{(17)}$ reported on five cases that underwent mosaicplasty on the patella, with unfavorable evolution. In that study, the authors suggested that the large difference in cartilage thickness between the donor and receptor sites compromised graft incorporation, thus making this technique contraindicated for treatment of patellar lesions.

In a recent prospective study on 10 patients, Figueroa et $\mathrm{al}^{(28)}$ concluded that patellar AOT was a good alternative for treating full-thickness patellar cartilage lesions, with good clinical, functional and imaging results over the medium term (three years of follow-up). The weak points of our study were the small num- ber of cases treated with patellar AOT, the lack of a control group for comparing effects and the short follow-up time.

\section{CONCLUSION}

Based on the results from the present study, we consider that autologous osteochondral transplantation is a good method for treating symptomatic full-thickness chondral lesions of the patellar joint surface. However, new good-quality prospective studies with larger samples and longer follow-ups need to be conducted in order to compare the results from this technique with those from other techniques in the literature.

\section{REFERÊNCIAS}

1. Marcacci M, Kon E, Delcogliano M, Filardo G, Busacca M, Zaffagnini S. Arthroscopic autologous osteochondral grafting for cartilage defects of the knee: prospective study results at a minimum 7-year follow-up. Am J Sports Med. 2007;35(12):2014-21.

2. Curl WW, Krome J, Gordon ES, Rushing J, Smith BP, Poehling GG. Cartilage injuries: a review of 31,516 knee arthroscopies. Arthroscopy. 1997;13(4):456-60.

3. Buckwalter JA, Mankin HJ. Articular cartilage: degeneration and osteoarthritis, repair, regeneration, and transplantation. Instr Course Lect. 1998;47:487-504

4. Cohen ZA, Roglic H, Grelsamer RP, Henry JH, Levine WN, Mow VC, et al. Patellofemoral stresses during open and closed kinetic chain exercises. An analysis using computer simulation. Am J Sports Med. 2001;29(4):480-7.

5. Grelsamer RP, Weinstein $\mathrm{CH}$. Applied biomechanics of the patella. Clin Orthop Relat Res. 2001;(389):9-14.

6. Lu AP, Hame SL. Autologous osteochondral transplantation for simple cyst in the patella. Arthroscopy. 2005;21(8):1008.

7. Huberti $\mathrm{HH}$, Hayes WC. Patellofemoral contact pressures. The influence of q-angle and tendofemoral contact. J Bone Joint Surg Am. 1984;66(5):715-24.

8. Nho SJ, Foo LF, Green DM, Shindle MK, Warren RF, Wickiewicz TL, et al. Magnetic resonance imaging and clinical evaluation of patellar resurfacing with press-fit osteochondral autograft plugs. Am J Sports Med. 2008;36(6):1101-9.

9. Lane JG, Tontz WL Jr, Ball ST, Massie JB, Chen AC, Bae WC, et al. A morphologic, biochemical, and biomechanical assessment of short-term effects of osteochondral autograft plug transfer in an animal model. Arthroscopy. 2001;17(8):856-63.

10. Brittberg M, Winalski CS. Evaluation of cartilage injuries and repair. $J$ Bone Joint Surg Am. 2003;85(Suppl 2):58-69.

11. Hangody L, Fules P. Autologous osteochondral mosaicplasty for the treatment of full-thickness defects of weight-bearing joints: ten years of experimental and clinical experience. J Bone Joint Surg Am. 2003;85(Suppl 2):25-32.

12. Atik OS, Uslu MM, Eksioglu F. Osteochondral multiple autograft transfer (OMAT) for the treatment of cartilage defects in the knee joint. Bull Hosp Jt Dis. 2005;63(1-2):37-40.

13. Miniaci A, Tytherleigh-Strong G. Fixation of unstable osteochondritis dissecans lesions of the knee using arthroscopic autogenous osteochondral grafting (mosaicplasty). Arthroscopy. 2007;23(8):845-51.

14. Hangody L, Rathonyi GK, Duska Z, Vasarhelyi G, Fules P, Modis L. Autologous osteochondral mosaicplasty. Surgical technique. J Bone Joint Surg Am. 2004;86(Suppl 1):65-72.

15. Chow JC, Hantes ME, Houle JB, Zalavras CG. Arthroscopic autogenous osteochondral transplantation for treating knee cartilage defects: a 2- to 5-year follow-up study. Arthroscopy. 2004;20(7):681-90.
16. Redman SN, Oldfield SF, Archer CW. Current strategies for articular cartilage repair. Eur Cell Mater. 2005;9:23-32.

17. Bentley G, Biant LC, Carrington RW, Akmal M, Goldberg A, Williams AM, et al. A prospective, randomised comparison of autologous chondrocyte implantation versus mosaicplasty for osteochondral defects in the knee. J Bone Joint Surg Br. 2003;85(2):223-30.

18. Lira Neto OA, Franciozi CE, Granata Júnior GS, de Queiroz AA, Carneiro Filho M, Navarro RD. Tratamento cirúrgico das lesões osteocondrais do joelho com mosaicoplastia. Rev Bras Ortop. 2010;45(2):166-73.

19. Mainil-Varlet $P$, Aigner T, Brittberg M, Bullough $P$, Hollander A, Hunziker E, et al. Histological assessment of cartilage repair: a report by the Histology Endpoint Committee of the International Cartilage Repair Society (ICRS). J Bone Joint Surg Am. 2003;85(Suppl 2):45-57.

20. Bobic V. Arthroscopic osteochondral autograft transplantation in anterior cruciate ligament reconstruction: a preliminary clinical study. Knee Surg Sports Traumatol Arthrosc. 1996;3(4):262-4

21. Hangody L, Kish G, Karpati Z, Szerb I, Udvarhelyi I. Arthroscopic autogenous osteochondral mosaicplasty for the treatment of femoral condylar articular defects. A preliminary report. Knee Surg Sports Traumatol Arthrosc. 1997;5(4):262-7.

22. Visonà E, Chouteau J, Aldegheri R, Fessy MH, Moyen B. Patella osteochondritis dissecans end stage: The osteochondral mosaicplasty option. Orthop Traumatol Surg. Res. 2010;96(5):543-8

23. Mitchell N, Shepard N. The resurfacing of adult rabbit articular cartilage by multiple perforations through the subchondral bone. J Bone Joint Surg Am. 1976;58(2):230-3.

24. Derrett S, Stokes EA, James M, Bartlett W, Bentley G. Cost and health status analysis after autologous chondrocyte implantation and mosaicplasty: a retrospective comparison. Int J Technol Assess Health Care. 2005 Summer;21(3):359-67.

25. Horas U, Pelinkovic D, Herr G, Aigner T, Schnettler R. Autologous chondrocyte implantation and osteochondral cylinder transplantation in cartilage repair of the knee joint. A prospective, comparative trial. J Bone Joint Surg Am. 2003;85(2):185-92.

26. Wagner H. [Surgical Treatment of Osteochondritis Dissecans, a Cause of Arthritis Deformans of the Knee]. Rev Chir Orthop Reparatrice Appar Mot. 1964;50:335-52.

27. Jakob RP, Franz T, Gautier E, Mainil-Varlet P. Autologous osteochondral grafting in the knee: indication, results, and reflections. Clin Orthop Relat Res. 2002;(401):170-84.

28. Figueroa D, Meleán P, Calvo R, Gili F, Zilleruelo N, Vaisman A. Osteochondral autografts in full thickness patella cartilage lesions. Knee. 2011;18(4):220-3 